\title{
Effect of bioeffectors and recycled P-fertiliser products on the growth of spring wheat
}

\author{
Jonas Duus Stevens Lekfeldt ${ }^{1}$, Martin Rex², Filip Mercl ${ }^{3}$, Martin Kulhánek ${ }^{3}$, Pavel Tlustoš ${ }^{3}$, Jakob Magid ${ }^{1}$ \\ and Andreas de Neergaard ${ }^{1 *}$
}

\begin{abstract}
Background: The recycling of waste products into $P$ fertilisers in agriculture is advisable from the perspective of sustainability. Bioeffectors (BEs), which have the ability to increase the plant uptake of $\mathrm{P}$ from recycled fertiliser products, may increase the fertiliser value of these products. This paper investigated the effect of a range of different recycled fertilisers on the growth and P uptake of wheat in pot experiments conducted at three different locations in Europe. Furthermore, investigations were undertaken as to whether the addition of a range of bioeffectors could significantly enhance $P$ availability, $P$ uptake and plant growth.

Results: BE additions were found not to significantly increase the aboveground biomass of wheat plants or the uptake of $\mathrm{P}$ when plants were fertilised with recycled fertiliser products. This was shown across a range of pot experiments with soils of different P status. Only in the case of the positive control P fertiliser (TSP) was a positive effect of Proradix and RhizoVital on plant growth observed in one of the experiments, while in the same experiment RhizoVital and Biological fertiliser DC had a negative impact on plant biomass when the P fertiliser was Thomas phosphate. With regard to P uptake, there was only a slight positive effect of Proradix in plants not supplied with P fertiliser in this experiment. Clear differences were seen in the efficiency of P fertilisers. Generally, sewage sludge ash performed quite poorly (20-40\% of TSP), while sewage sludge, Thomas phosphate, P-enriched slag and the fibre fraction of pig manure all had a high availability of $\mathrm{P}(>74 \%$ relative to TSP). Compost composed mainly of garden/park waste and sewage sludge was intermediate in availability (40-70\%). The elemental composition of the harvested wheat plants was significantly affected in all cases by the different $P$ fertilisers added. The BE treatments significantly affected the elemental composition of the aboveground biomass in one of the experiments where the product Proradix had the greatest effect on elemental composition.
\end{abstract}

Conclusions: In conclusion, the experiments revealed a wide difference in the bioavailability of $\mathrm{P}$ in the different waste products, but the added microorganisms demonstrated a limited capacity to influence plant $\mathrm{P}$ uptake across a range of soils and waste products.

\section{Background}

Phosphorus $(\mathrm{P})$ is a non-renewable resource [1], and currently the majority of $\mathrm{P}$ added as fertiliser in agriculture is in the form of inorganic fertilisers. From a sustainability

\footnotetext{
*Correspondence: adn@plen.ku.dk

${ }^{1}$ Department of Plant and Environmental Sciences, Section of Plant and Soil Science, University of Copenhagen, Thorvaldsensvej 40, 1871 Frederiksberg, Denmark

Full list of author information is available at the end of the article
}

point of view, it is sensible to make better use of P resources that are discarded as waste from urban areas; hence, there is a need to improve the recycling of $P$ from agricultural and urban wastes [2]. Recycled fertiliser products are by no means homogenous and the availability of $\mathrm{P}$ for plant uptake from recycled fertiliser products may vary considerably, depending on the feedstock of the fertiliser and the subsequent type of processing [3]. Sewage sludge as a fertiliser may contain a range of different $\mathrm{P}$ forms depending 
on the specific process used to recover $\mathrm{P}$ from the sewage water, but a precipitation reaction using $\mathrm{Al}, \mathrm{Fe}, \mathrm{Mg}$ or Ca to precipitate P is often employed [3]. Sewage sludge may contain different types of organic contaminants [4]. Although it is still used as a fertiliser in many countries across Europe [5], the use of sewage sludge has declined in a number of European countries, while sewage sludge application on agricultural land was banned in Switzerland in 2008 [6]. A common practice that eliminates the organic contaminants in sludge is to incinerate the sewage sludge, thus producing sewage sludge ash. However, the availability of $\mathrm{P}$ in sewage sludge ash is quite low, but is also observed to be variable depending on the type of treatment in the sewage treatment plant [7]. Techniques such as acid leaching and thermal treatment have been investigated for their potential to recover P from sewage sludge ash while separating it from the detrimental heavy metals with varying success [5, 7], but there is also a possibility of combining the upgrading of sewage sludge ash with the recycling of metallurgical slags. Slags from the metallurgical industry had been recycled as fertiliser in Germany in the form of Thomas phosphate for more than 100 years, but this is no longer produced [8]. BOF (basic oxygen furnace) or LD (Linz-Donawitz) slag from steel production may be used as a liming agent in agriculture [8]. It is also possible, however, to use sewage sludge ash as a means to enrich the hot liquid BOF slag with $\mathrm{P}$, resulting in a fertiliser with a markedly higher $\mathrm{P}$ availability compared to the feedstock sewage sludge ash, due to a conversion of $\mathrm{Ca}_{3}\left(\mathrm{PO}_{4}\right)_{2}$ (whitlockite) of low neutral ammonium citrate (nac) solubility into Casilico-phosphates with a higher nac solubility [9]. P contained in animal manures can be used more sustainably if it is up-concentrated, and thereby more easily transported from areas with a $\mathrm{P}$ surplus to areas where soils have a $\mathrm{P}$ deficit [3]. The majority of $\mathrm{P}(60-90 \%)$ found in pig manure is inorganic [10] and only very little is in the form of phytate $[11,12]$. Biomass ash (e.g. wood and straw ash) from bioenergy-plants could also potentially serve as a $P$ fertiliser [13].

Different types of biostimulants or bioeffectors (BEs) have been investigated for their ability to increase plant productivity in agricultural systems [14]. The concept of BEs covers quite a diverse group of natural products [15]. In the present paper, the scope was limited to plant growth-promoting microorganisms (PGPM) focusing on plant growth-promoting rhizobacteria (PGPR) [16] and free-living fungi, such as species of the genus Trichoderma [17]. PGPM may have the potential to enhance plant uptake of $P$ from soil $[14,18$, 19]. Improved growth under P-limiting soil conditions as a result of microbial inoculations has been observed in many different plant species, such as mung bean [17], bean [20], maize [21] and wheat [22]. In soil, a large proportion of the total P pool is not directly available for plant uptake [23], and the ability to solubilise phosphates in the rhizosphere has been viewed as an important function of PGPM [24]. The plant growth-promoting effect may, however, be overestimated due to a publication bias, and an observed positive plant growth response may be due to mechanisms other than an increased availability of $\mathrm{P}$ in the rhizosphere brought about by PGPM solubilisation of P, e.g. changes in root architecture and total root length [24].

Further research is therefore required into the potential of BEs to facilitate the plant uptake of nutrients from soil. Fungi of the ascomycete genera Trichoderma and Penicillium have been extensively studied for their potential as PGPM [25], and fungi of the genus Trichoderma may have an ability to increase plant nutrient uptake from soil [26, 27]. The specific T. harzianum strain Rifai 1295-22 (T22) has been observed to increase the solubilisation of sparingly soluble calcium phosphates [28] and to have a plant growth-promoting effect in willow [29], chickpea [17] and maize [30]. Fungi of the genus Penicillium have been shown to have P-solubilising capabilities [31, 32], and members of this genus have been observed to have a positive effect on biomass and $\mathrm{P}$ uptake of wheat and bean [20]. Wakelin et al. [33] found that a strain of P. bilaii is both capable of increasing the yield of medic and lentil in the field and of significantly increasing the level of $\mathrm{HCO}_{3}-$ extractable $\mathrm{P}$ in soil microcosms, and more recently $P$. bilaii has been found to increase yield in maize in field trials [21]. On the other hand, the positive effect of P. bilaii under P-limited conditions has also been linked in pea to an increase in the root adsorptive capacity under P-limited conditions rather than through increased P solubilisation [34]. However, an investigation across a number of field studies involving wheat showed that $P$. bilaii does not significantly affect $\mathrm{P}$ uptake and yield [35]. Gram-negative gammaproteobacteria of the genus Pseudomonas are ubiquitous bacteria in soil, are known to proliferate greatly in the rhizosphere [36] and have been studied for their plant growth-promoting activities for many years [37]. Bacteria from this genus have been observed to increase plant productivity under P-limiting conditions [38, 39]. As a representative of Pseudomonas PGPR, the product Proradix was selected. This product has primarily been developed and investigated for its effects on plant resistance to pathogens [40-42], but there is also evidence that this product may improve plant growth under nutrient-limiting conditions [43]. Low $\mathrm{G}+\mathrm{C}$ Gram-positive bacteria of the genus Bacillus have been shown to solubilise calcium phosphates and increase the dry matter yield of wheat in a pot trial in which no $P$ fertiliser or calcium phosphates were applied [22]. A number of $B$. amyloliquefaciens strains have been investigated for their biocontrol capabilities [44] and the type strain (FZB42) for the subspecies plantarum of B. amyloliquefaciens [45] is reported to work as a biofertiliser and provide protection against various soil-borne diseases [46, 47].

The aim of the present paper was to investigate whether a variety of $\mathrm{BE}$ organisms could significantly enhance 
the availability and uptake of $\mathrm{P}$ from a range of recycled $P$-fertiliser products with very different $P$ availability. The paper encompasses a number of pot experiments carried out in Denmark, Germany and the Czech Republic. The experiments included a negative control as well as a positive control (in two out of three studies) in which highly available triple superphosphate was added.

Sewage sludge ash in particular is an example of a product with quite low $\mathrm{P}$ solubility, offering considerable potential for improvement by BEs. The microorganisms were expected to have a positive effect on the solubilisation of fertiliser-derived $\mathrm{P}$ in the soil, as well as a direct effect on the plants through hormonal effects. The latter effects might occur in all P-addition treatments, whereas the positive effects on soil $\mathrm{P}$ availability are expected to be of greater significance in treatments with lower $P$ availability, such as sewage sludge ash. It was therefore hypothesised that: (i) inoculation with the selected $\mathrm{BE}$ strains would increase the availability of $P$ from the recycled fertilisers and (ii) inoculation with the selected $\mathrm{BE}$ strains would increase the uptake of $P$ by wheat from soil, leading to a larger production of aboveground biomass.

Due to differences in the conditions between the individual experiments, it is not possible to compare the concentrations of elements or biomass produced per kg soil across experiments. We therefore only analyse the relative changes in, for instance, biomass compared to the negative and positive controls (where included) across experiments. We analyse the effect of BEs in the individual experiments. The fact that some of the BEs are tested using different soils and slightly different growing conditions serves as a stronger test of their performance than a single pot experiment would have.

\section{Methods}

The paper deals with the results of three separate pot trials. The pot trials were carried out at Arbeitsgemeinschaft Hüttenkalk e.V., Germany (HK Kalke experiment), the University of Copenhagen, Denmark (UCPH experiment), and the Czech University of Life Sciences Prague, Czech Republic (CULS experiment).

\section{Sampling of soil and soil characterisation}

The three pot experiments included in this publication were performed with four different soils (Table 1). Soil for the HK Kalke experiment was sampled from the plough layer of a field with arable feed production that had not had any $P$ fertilisation for over 30 years, located in Marienmünster-Vörden in East Westphalia, Germany. Soil for the UCPH experiment was sampled from the plough layer of the long-term nutrient depletion trial at the University of Copenhagen's experimental farm in Taastrup, Denmark, where cereals have been grown continuously for more than 50 years without the addition of P fertilisers. Finally, the soils used in the CULS pot experiment were sampled from the plough layer of either the long-term experimental farm in Humpolec, Czech Republic, where wheat, potato and barley were grown in rotation continuously without fertilisation for 20 years (Humpolec soil), or a field managed by a conventional farming system with low P inputs (Poděbrady soil). The air-dried soil was analysed in the laboratory of the Landesanstalt für Landwirtschaftliche Chemie at the University of Hohenheim, Germany, for the HK Kalke and $\mathrm{UCPH}$ experiments. Selected results of these analyses are presented in Table 1. Texture was analysed using a combination of wet sieving and pipetting according to the VDLUFA standard method C 2.2.1 [48]. Organic carbon content was measured according to the VDLUFA standard method A 4.1.3.1 [48]. $\mathrm{pH}$ was measured in $0.01 \mathrm{M}$ $\mathrm{CaCl}_{2}$ according to the VDLUFA standard method A 5.1.1 [48]. Finally, calcium-acetate lactate-extractable P $\left(P_{\text {CAL }}\right)$ was measured according to the VDLUFA standard method A 6.2.1.1 [48]. The soils for the CULS experiments were analysed at the Czech University of Life Sciences following the same protocols.

Table 1 Soil data

\begin{tabular}{|c|c|c|c|c|c|c|c|c|}
\hline \multirow[t]{2}{*}{ Soil } & \multirow[t]{2}{*}{ Management } & \multicolumn{3}{|c|}{ Texture (\%) } & \multirow[t]{2}{*}{ OC (\%) } & \multirow[t]{2}{*}{$\mathrm{pH}^{\mathrm{a}}$} & \multirow{2}{*}{$\begin{array}{l}P_{\mathrm{CAL}} \\
\left(\mathrm{mg} \mathrm{kg}^{-1}\right)\end{array}$} & \multirow{2}{*}{$\begin{array}{l}P_{\text {TOT }} \\
\left(\mathrm{mg} \mathrm{kg}^{-1}\right)\end{array}$} \\
\hline & & Sand & Silt & Clay & & & & \\
\hline Vörden ${ }^{b}$ & $\begin{array}{l}\text { Conventional farming system. Arable land food } \\
\text { production. No P addition for more than } 30 \text { years }\end{array}$ & 41.1 & 46.9 & 12.0 & 0.8 & 5.0 & 26 & 310 \\
\hline NDT-A & $\begin{array}{l}\text { Continuous cropping. No addition of } \mathrm{P} \text { fertiliser } \\
\text { for more than } 30 \text { years }\end{array}$ & 55.4 & 31.2 & 13.4 & 1.1 & 5.8 & 35 & 397 \\
\hline Humpolec ${ }^{c}$ & $\begin{array}{l}\text { Continuous cropping (potato, wheat, barley). } \\
\text { No addition of P fertilisers }\end{array}$ & 30 & 49 & 21 & 1.6 & 4.5 & 59 & 587 \\
\hline Poděbradyc & Conventional farming system. Low P input & 57 & 24 & 19 & 1.9 & 6 & 30 & 384 \\
\hline
\end{tabular}

${ }^{a} \mathrm{pH}$ measured in $\mathrm{CaCl}_{2}$

b Data were recorded on the 2:1 soil:sand mixture used in the pot experiments

c Data were recorded on the pure soil 


\section{Bioeffector (BE) treatments}

A range of different bioeffectors (BEs) was added to the growth medium at sowing. A control treatment without the addition of BEs was included (BE0). The BEs investigated were a Trichoderma harzianum isolate marketed as Trianum-P by Koppert (TrP), Proradix (Pro) from Sourcon Padena containing Pseudomonas sp., RhizoVital $42(\mathrm{RhVi})$ produced by ABiTEP containing Bacillus amyloliquefaciens ssp. plantarum, strain FZB42, biological fertiliser DC (Bio-DC) produced by Bayer Crop Science Biologics GmbH containing Penicillium sp. and BactoProf (BaPr) produced by Terra Bioscience, Germany, which contains isolates of T. harzianum and five species of Bacillus. BE suspensions were prepared in $0.25 \mathrm{mM} \mathrm{CaSO}_{4}$. The concentrations used for the inoculation are given in Table 2.

\section{$P$ fertilisers and $\mathrm{P}$-fertilisation treatments}

A number of recycled $P$ fertilisers were applied in the experiment (Table 3). Thomas phosphate was obtained from the Luxengrais steel plant in Luxembourg. Sewage sludge and sewage sludge ash for the HK Kalke experiment were obtained from a municipal treatment plant in Bonn, processing wastewater mainly from households and from an attached sewage sludge incineration plant. The sewage sludge and sewage sludge ash used for the UCPH experiment originated from a public treatment plant receiving wastewater from households and industries (Spildevandscenter Avedøre). A P-enriched steelmaking slag (LDS/SSA in the HK Kalke experiment) was produced by blowing sewage sludge ash into a liquid $1500{ }^{\circ} \mathrm{C}$ basic oxygen furnace slag (prepared by the Linz-Donawitz process) from a steelwork in Salzgitter [9]. A fibre fraction of pig manure (FFPM) was obtained using the decanter centrifuge method. A compost (Comp) consisting of a mixture of mainly garden park waste and sewage sludge (42\% garden park waste, $36 \%$ sewage sludge, $14 \%$ straw and horse manure, $8 \%$ wood mass) was obtained from the private company KomTek, Denmark. Straw ash (StA) was a mixture of fly and bottom ash from a grate-fired boiler (15 MWt) and originated from cereal straw combustion. Finally, wood ash (WoA) was obtained from a fluidised bed reactor (15 MWt) in which wood chips were combusted.

For the majority of the fertilisers, the equivalent of $50 \mathrm{mg} \mathrm{P} \mathrm{kg}{ }^{-1}$ soil was added. There were, however, some deviations from this in the CULS experiment (Table 3). For both the HK Kalke experiment and the UCPH experiment, sewage sludge (SS) and sewage sludge ashes (SSA) were included. Furthermore, both TSP and a low-grade type of TSP, termed superphosphate (SP) here, were included in both these experiments as positive controls. In all three experiments, a negative control without the addition of $\mathrm{P}$ fertiliser (P0) was included. An overview of the $\mathrm{BE}$ and P-fertilisation treatments included in the three pot experiments is presented in Table 4.

\section{Pot trial setup, growing conditions and harvest}

Soil preparation, growing conditions, harvest days and nutrient application are presented in Table 5.

\section{HK Kalke experiment}

The air-dried and sieved soil (mesh size $5 \mathrm{~mm}$ ) was mixed with water-washed quartz sand in a proportion of 2:1. This substrate was mixed with $0.843 \mathrm{~g} \mathrm{~kg}^{-1}$ $\mathrm{Ca}\left(\mathrm{NO}_{3}\right)_{2} \cdot 4 \mathrm{H}_{2} \mathrm{O}$ and $0.719 \mathrm{~g} \mathrm{~kg}^{-1}$ Patentkali $\left(27.8 \% \mathrm{~K}_{2} \mathrm{O}\right.$, $9.49 \% \mathrm{MgO}, 15.8 \% \mathrm{~S}$ ). Each pot was filled with $6 \mathrm{~kg}$ of the fertilised soil/sand mixture and watered to $70 \%$ of WHC. Before watering, Bio-DC was mixed into the substrate of the Bio-DC treatment. Spring wheat (cultivar Aranka) was sown in 32 separate sowing holes (approximately, $2 \mathrm{~cm}$ deep). To each of the sowing holes, $2 \mathrm{ml}$ of the Pro or RhVi suspensions were added in the corresponding $\mathrm{BE}$ treatments. After germination, plants were reduced to 24 wheat plants per pot. The pots were placed in a randomised design, with four replicates per treatment, in an outdoor roofed vegetation hall. Pots were irrigated with demineralised water to 60-70\% WHC (controlled gravimetrically once a week) during the whole vegetation

Table 2 Bioeffector (BE) products applied in the experiments

\begin{tabular}{|c|c|c|c|c|c|}
\hline Product & Producer & Abbr. & Name of organism(s) & $\begin{array}{l}\text { Type of } \\
\text { organism }\end{array}$ & $\begin{array}{l}\text { Application rate } \\
\text { (cfu g } \mathrm{g}^{-1} \text { soil) }\end{array}$ \\
\hline Control & n.a. & BEO & n.a. & n.a. & n.a. \\
\hline Trianum-P, T22 & Koppert, The Netherlands & $\operatorname{TrP}$ & Trichoderma harzianum, strain T-22 & Fungi & $2.5 \cdot 10^{4}$ \\
\hline Proradix & Sourcon Padena, Germany & Pro & Pseudomonas sp., strain DSMZ 13134 & Bacteria & $2 \cdot 10^{6}$ \\
\hline RhizoVital 42 & ABiTEP, Germany & RhVi & Bacillus amyloliquefaciens & Bacteria & $2 \cdot 10^{6}$ \\
\hline Biological fertiliser DC & Beyer/Prophyta, Germany & Bio-DC & Penicillium sp. & Fungi & $1 \cdot 10^{5}$ \\
\hline Bacto prof & Terra Bioscience, Germany & $\mathrm{BaPr}$ & T. harzianum and five species of Bacillus & $\begin{array}{l}\text { Bacteria }+ \\
\text { fungi }\end{array}$ & $2 \cdot 10^{6}$ \\
\hline
\end{tabular}


Table 3 P-fertilisation treatments applied in the experiments

\begin{tabular}{|c|c|c|c|c|c|}
\hline P fertiliser & $\begin{array}{l}\text { Treatment } \\
\text { abbreviation }\end{array}$ & $\begin{array}{l}\text { Total } \mathrm{P} \text { content in } \\
\text { product }\left(\mathrm{g} \mathrm{kg}^{-1}\right)\end{array}$ & $\begin{array}{l}\text { Water-extractable } \\
\mathrm{P}(\% \text { of total } \mathrm{P})\end{array}$ & $\begin{array}{l}\text { App. rate (g dry } \\
\text { product } \mathbf{k g}^{-1} \text { soil) }\end{array}$ & $\begin{array}{l}\mathrm{P} \text { app. rate } \\
\text { ( } \mathrm{mg} \mathrm{P} \mathrm{kg} \text { kg }^{-1} \text { soil) }\end{array}$ \\
\hline Negative control & PO & n.a. & n.a. & n.a. & n.a. \\
\hline Triple superphosphate & TSP & 200 & 43.3 & 0.25 & 50 \\
\hline Superphosphate & $\mathrm{SP}$ & 81 & 11.4 & 0.62 & 50 \\
\hline Thomas phosphate & Thph & 68 & 0 & 0.73 & 50 \\
\hline Sewage sludge, HK Kalke & SS & 36 & n.d. & 1.40 & 50 \\
\hline Sewage sludge, UCPH & SS & 37 & n.d. & 1.36 & 50 \\
\hline Sewage sludge ash, HK Kalke & SSA & 103 & 0.18 & 0.48 & 50 \\
\hline Sewage sludge ash, UCPH & SSA & 89 & n.d. & 0.56 & 50 \\
\hline Fibre fraction of pig manure & FFPM & 2.4 & n.d. & & 50 \\
\hline SSA-enriched LD slag & LDS/SSA & 17 & 0 & 2.92 & 50 \\
\hline $\begin{array}{l}\text { Compost mainly consisting of sewage } \\
\text { sludge and garden/park waste }\end{array}$ & Comp & $3.6^{a, b}$ & n.d. & $13.8^{\mathrm{b}}$ & 50 \\
\hline Ashes from cereal straw & StA & 13.6 & 6.5 & 10 & 136 \\
\hline Ashes from wood chips & WoA & 10.2 & 0.05 & 10 & 102 \\
\hline Dipotassium phosphate & DKP & 178 & 100 & 0.18 & 32 \\
\hline
\end{tabular}

according to information from the producer

b These measurements are in $\mathrm{g} \mathrm{kg}^{-1}$ fresh matter

period. The plants were supplemented with an additional $50 \mathrm{mg} \mathrm{N} \mathrm{kg}{ }^{-1}$ soil on day 40 in the form of $\mathrm{Ca}\left(\mathrm{NO}_{3}\right)_{2}$. The plants were harvested 8 weeks after sowing. The plants were at stage 59 (without $P$ fertilisation) or stage 63 (with $\mathrm{P}$ fertilisation).

\section{UCPH experiment}

Soil was partially air dried and sieved (mesh size $5 \mathrm{~mm}$ ). The soil was mixed with quartz sand in the proportion of $1: 1$. The water-holding capacity of the soil/sand mixture was determined. For each pot, $2.5 \mathrm{~kg}$ of the soil/ sand mixture was mixed with $0.645 \mathrm{~g} \mathrm{~kg}^{-1} \mathrm{Ca}\left(\mathrm{NO}_{3}\right)_{2}$ and $0.667 \mathrm{~g} \mathrm{~kg}^{-1}$ Patentkali $\left(30 \% \mathrm{~K}_{2} \mathrm{O}, 10 \% \mathrm{MgO}, 42.5 \%\right.$ $\mathrm{SO}_{3}$ ). Subsequently, this substrate was mixed with either $50 \mathrm{~g}$ sand (P0 treatment) or $50 \mathrm{~g}$ sand mixed with one of the $\mathrm{P}$ fertilisers being investigated (Table 5). The fertilisers were mixed with sand prior to being added to the soil to ensure thorough mixing throughout the whole soil volume. The soil was watered to $40 \%$ of WHC. Fifteen wheat seeds (cultivar Scirocco, KWS) were sown in separate sowing holes (approximately, $2 \mathrm{~cm}$ deep). After the seeds were sown, $1 \mathrm{~mL}$ of $\mathrm{BE}$ suspension (or $0.25 \mathrm{mM} \mathrm{CaSO}_{4}$ in the $\mathrm{BE} 0$ controls) was added to each of the sowing holes before these were closed. For each treatment, five replicate pots were set up, resulting in a total of 140 pots in the experiment. The pots were placed in a greenhouse in a randomised block design. After germination, the wheat plants were thinned out, leaving ten plants in each pot. During the experiment, the pots were watered to weight (initially, $60 \%$ and subsequently $70 \%$ of WHC) at regular intervals (every 1-3 days).
The blocks were rotated and reshuffled once or twice a week during the experiment. At 25 days after sowing, the youngest fully developed leaf was removed from one plant in three replicates of the BE0 treatments (all P treatments), giving a total of 21 samples. After 32 days, five plants from each pot were harvested. After 42 days, extra $\mathrm{N}$ was added to each pot (33 $\mathrm{mg} \mathrm{N} \mathrm{kg}^{-1}$ soil). After 54 days, the remaining five plants were harvested from each pot. At harvest, the plants were at stage 55 . A follow-up experiment partially replicating the UCPH experiment was carried out as well (see Additional file 1 for details).

\section{CULS experiment}

Soil was air dried and sieved (mesh size $10 \mathrm{~mm}$ ). No sand was added to the soil. For each pot, $5 \mathrm{~kg}$ (d.w.) of soil was used, which was mixed with $1.67 \mathrm{~g}$ of $\mathrm{NH}_{4} \mathrm{NO}_{3} .50 \mathrm{~g}$ of WoA or StA was thoroughly mixed with the soil prior to filling the pots (final dose $10 \mathrm{~g}$ of ash per $\mathrm{kg}$ soil). $\mathrm{K}_{2} \mathrm{HPO}_{4}$ was applied as a water solution and was also thoroughly mixed into the whole soil volume. The soil was watered to $40 \%$ of WHC, 25 wheat seeds (cultivar Aranka) were sown in separate sowing holes (approximately, $2 \mathrm{~cm}$ deep) and $2 \mathrm{ml}$ of $\mathrm{BE}$ suspension (or $0.25 \mathrm{mM} \mathrm{CaSO}_{4}$ in the $\mathrm{BEO}$ controls) was applied to each hole prior to closing. After germination, the number of plants was reduced to 20 wheat plants per pot, and these were inoculated again by irrigation with $100 \mathrm{ml}$ of BE suspension per pot. The pots were placed in an outdoor roofed vegetation hall. Pots were irrigated with demineralised water to 60-70 \% WHC (controlled gravimetrically once a week) 
Table 4 Overview of the treatments applied in the different experiments (soils)

\begin{tabular}{|c|c|c|c|c|}
\hline \multirow[t]{2}{*}{ Soil } & \multirow{2}{*}{$\begin{array}{l}\text { 1. HK Kalke } \\
\text { (Germany) } \\
\text { Vörden }\end{array}$} & \multirow{2}{*}{$\begin{array}{l}\text { 2. UCPH } \\
\text { (Denmark) } \\
\text { NDT }\end{array}$} & \multicolumn{2}{|c|}{$\begin{array}{l}\text { 3. CULS } \\
\text { (Czech Republic) }\end{array}$} \\
\hline & & & Humpolec & Poděbrady \\
\hline \multicolumn{5}{|l|}{ Bio-effectors } \\
\hline $\begin{array}{l}\text { Negative } \\
\text { control (BE0) }\end{array}$ & $x$ & $x$ & $x$ & $x$ \\
\hline $\operatorname{TrP}$ & & $x$ & & \\
\hline Pro & $x$ & $x$ & & \\
\hline RhVi & $x$ & $x$ & $x^{a}$ & $x^{a}$ \\
\hline Bio-DC & $x$ & & & \\
\hline $\mathrm{BaPr}$ & & & $x^{a}$ & $x^{a}$ \\
\hline \multicolumn{5}{|l|}{ P fertilisers } \\
\hline $\begin{array}{l}\text { Negative } \\
\text { control (P0) }\end{array}$ & $x$ & $x$ & $x^{b}$ & $x^{b}$ \\
\hline DKP & & & $x^{b}$ & $x^{b}$ \\
\hline TSP & $x$ & $x$ & & \\
\hline $\mathrm{SP}$ & $x$ & $x$ & & \\
\hline Thph & $x$ & & & \\
\hline SS & $x$ & $x$ & & \\
\hline FFPM & & $x$ & & \\
\hline Comp & & $x$ & & \\
\hline SSa & $x$ & $x$ & & \\
\hline LDS/SSA & $x$ & & & \\
\hline StA & & & $x$ & $x$ \\
\hline WoA & & & $x$ & $x$ \\
\hline
\end{tabular}

a Only in combination with StA and WoA

b Only in combination with BEO

during the entire vegetation period. The experiment was undertaken in a randomised design with four randomisation procedures during the experiment. The plants were harvested after 16 weeks. At harvest, the plants were at full maturity.

\section{Soil data recorded during the HK Kalke experiment}

Soil ( $40 \mathrm{~g}$ ) was sampled 27 days after sowing. The soil was air dried and completely passed through a $2 \mathrm{~mm}$ mesh sieve. For $\mathrm{pH}$ measurement, $10 \mathrm{~g}$ of soil was suspended in $25 \mathrm{ml}$ of a 0.01 molar $\mathrm{CaCl}_{2}$ solution for $1 \mathrm{~h}$, stirred twice and $\mathrm{pH}$ determined using a $\mathrm{pH}$ electrode (VDLUFA standard method A 5.1.1). For water extraction of soil phosphate according to Van der Paauw [49] and Murphy and Riley [50], $4.25 \mathrm{ml}$ of soil was suspended in demineralised water for approximately $22 \mathrm{~h}$. Thereafter $250 \mathrm{ml}$ water was added; the mixture was mechanically shaken for $1 \mathrm{~h}$ and filtered. P determination was undertaken using a spectrophotometer and molybdenum blue method.

\section{Plant analyses}

\section{HK Kalke experiment}

After harvest, the aboveground wheat plant material was dried at $60{ }^{\circ} \mathrm{C} .400 \mathrm{mg}$ of plant material was digested with $8 \mathrm{ml} 69 \% \mathrm{HNO}_{3}$ supra and $1 \mathrm{ml} 15 \% \mathrm{H}_{2} \mathrm{O}_{2}$ in high-pressure MARS express vessels in a MARS microwave digestion system. The element analyses of $\mathrm{P}, \mathrm{K}, \mathrm{Mg}, \mathrm{Ca}, \mathrm{Mn}$ and $\mathrm{Na}$ were performed by ICP-OES.

\section{UCPH and CULS experiment}

The plant material was dried at $65{ }^{\circ} \mathrm{C}$ and weighed to measure the dry aboveground biomass. For elemental analysis, the dry plant material was finely ground. Subsequently, $100 \mathrm{mg}$ of dry plant material was mixed with $2.5 \mathrm{ml} 70 \% \mathrm{HNO}_{3}$ and $1 \mathrm{ml} 15 \% \mathrm{H}_{2} \mathrm{O}_{2}$, followed by digestion in a pressurised single-chamber microwave oven (UltraWAVE, Milestone Srl, BG, Italy). Samples were then diluted to $50 \mathrm{ml}$ using Milli-Q water and analysed for their elemental content $(\mathrm{B}, \mathrm{Ca}, \mathrm{Cu}, \mathrm{Fe}$, $\mathrm{K}, \mathrm{Mg}, \mathrm{Mn}, \mathrm{P}, \mathrm{S}, \mathrm{Zn}$ in $\mathrm{UCPH}$ and $\mathrm{Ca}, \mathrm{K}, \mathrm{Mg}, \mathrm{Mn}, \mathrm{Na}$, $\mathrm{P}$ in CULS) by ICP-OES. For the samples from the final harvest in the UCPH experiment, only $\mathrm{P}$ was measured using flow injection analysis.

\section{Data analyses and statistics}

The measurements of aboveground biomass were normalised relative to the control treatment (P0, BE0):

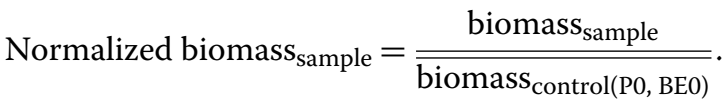

In the CULS experiment, the normalisation was undertaken separately for the two soils. Significance testing of differences between treatment means was performed using one- and two-way ANOVAs and Dunnett's test (for comparisons versus the control only) or Tukey's test (for all possible comparisons) for post hoc multiple comparisons. These were performed using the statistics module in Sigma Plot 13.0. In the UCPH experiment in which two separate samplings had been performed, the difference in normalised biomass between sampling days was tested using a paired $t$ test. For the CULS experiment, all the P-fertiliser treatments were combined with the BE0 treatment only. The effect of different P substrates was therefore analysed by a two-way ANOVA, excluding data for the RhVi and BaPr BE treatments. The effect of BE treatments in the CULS experiment was tested in two separate two-way ANOVAs for the two soils, where only data from the straw and wood ash treatments were included.

The efficiency of the fertilisers relative to TSP (positive control) was calculated as the mean efficiency measured 


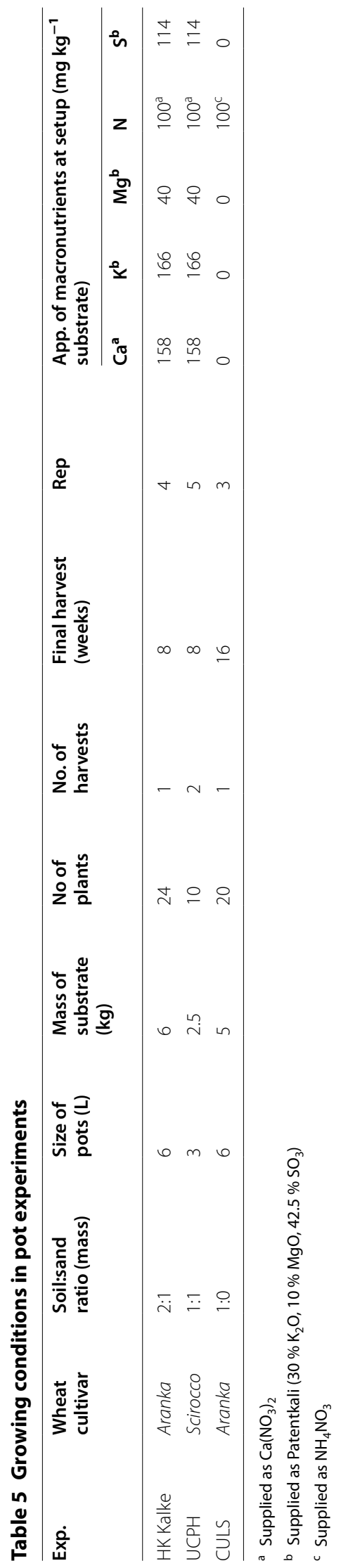


in $n$ replicate pots. The efficiency in the individual pots was calculated as follows where data were available:

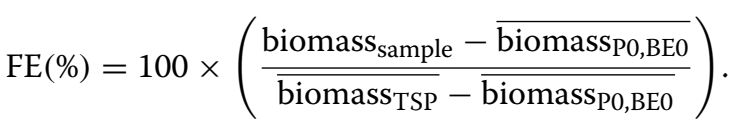

Similarly, the P-uptake efficiency from the different fertilisers was calculated as follows where the necessary data were available:

$\mathrm{PUE}(\%)=100 \times\left(\frac{\mathrm{P}_{\text {content }_{\text {sample }}}-\overline{\mathrm{P}_{\text {content }} \mathrm{P} 0, \mathrm{BE} 0}}{\overline{\mathrm{P}_{\text {content }} \mathrm{TSP}}-\overline{\mathrm{P} \text { content } \mathrm{P} 0, \mathrm{BE} 0}}\right)$.

The data for biomass in the HK Kalke experiment were expressed as a function of the available P level $\left(P_{\mathrm{H} 2 \mathrm{O}}\right)$ in the pot experiment and the three-parameter exponential rise to maximum (Mitscherlich) curve was fitted to the data [51]:

$$
y=y_{0}+a\left(1-e^{-\mathrm{bx}}\right) .
$$

The same model was used to express biomass as a function of the $\mathrm{P}$ concentration in the youngest fully developed leaf at day 25 in the UCPH experiment. These regressions and simple linear regressions were performed using the regression wizard in SigmaPlot 13.0 (Systat).

Principal component analysis (PCA) was performed on data for elemental concentrations. Beforehand, PCA data were standardised by subtracting the mean for each element and then dividing this by the standard deviation. PCA was performed in $\mathrm{R}$ version 3.1.1 [52] using the ade4 package [53] with a chosen number of principal components of 10 .

\section{Results}

\section{Aboveground biomass and $\mathrm{P}$ content HK Kalke experiment}

In the KALKE experiment (Fig. 1a), the normalised aboveground biomass was significantly different between the P-fertilisation treatments (two-way ANOVA, $P<0.001$ ) and BE treatments (two-way ANOVA, $P<0.05$ ), and there was a significant interaction between the two factors (two-way ANOVA, $P<0.001$ ). For the TSP treatment, the inoculation with Proradix and RhizoVital resulted in a significantly higher normalised aboveground biomass (Dunnett's test, $P<0.05)$. When Thomas phosphate (Thph) was applied as a $\mathrm{P}$ fertiliser, inoculating with Proradix and biological fertiliser DC resulted in a significantly lower normalised aboveground biomass compared to the BE0 control (Dunnett's test, $P<0.05$ ). For the remaining $\mathrm{P}$ fertilisers, the applied BEs (Pro, RhVi and Bio-DC) did not have a significant effect when compared with the control. The post hoc analysis of P-content data (Table 6a) showed that although there was a highly significant effect of both the $\mathrm{P}$ fertiliser, the $\mathrm{BE}$ application and the interaction between the two (two-way ANOVA, $P<0.001$ ), there was not a significant positive effect of any of the BE treatments on $\mathrm{P}$ uptake from any of the $\mathrm{P}$ fertilisers compared to the BE0 control (Dunnett's test, $P>0.05)$. Only in the P0 treatment, there was a significant positive effect of Pro and RhVi on total aboveground P content (Table 6a).

\section{UCPH experiment}

In the UCPH experiment, plants were harvested after 32 (Fig. 1b) and 54 days (Fig. 1c). The normalised biomass across all treatments was significantly different between harvests (paired $t$ test, $P<0.001$ ); therefore, the normalised aboveground biomass data from the two harvests were analysed individually. The normalised biomass was significantly different between P-fertilisation treatments at both harvests (two-way ANOVA, $P<0.001$ ). In contrast to this, the different $\mathrm{BE}$ inoculations did not affect the biomass obtained (two-way ANOVA, $P>0.05$ ) and no interaction was observed between the two factors (two-way ANOVA, $P>0.05$ ). At both harvests, all treatments in which a $P$ fertiliser was applied resulted in a significantly higher aboveground biomass than the control without added $P$ fertiliser (Dunnett's test, $P<0.05$ ). The absence of a significantly higher aboveground biomass when inoculating with the three BEs ( $\operatorname{TrP}$, Pro, $\mathrm{RhVi}$ ) compared to the uninoculated control (BE0) was confirmed for sewage sludge, sewage sludge ash and compost as the P fertilisers in a follow-up experiment at the University of Copenhagen in which only five wheat plants were grown in each pot (Additional file 1: Fig. S1). P uptake was only evaluated for the P fertilisers SSA and FFPM at the second harvest (Table $6 \mathrm{~b}$ ). No effect was produced by either of the two main factors ( $\mathrm{P}$ fertiliser and $\mathrm{BE}$ addition) and there was no interaction between the two factors in relation to the aboveground $\mathrm{P}$ content (two-way ANOVA, $P>0.05$ ).

\section{CULS experiment}

In the CULS experiment (Humpolec and Poděbrady soils), there was no significant effect of the soil type on the aboveground biomass in the control (P0/BE0) treatment (one-way ANOVA, $P>0.05$, data not shown). For the Humpolec soil, the DKP treatment yielded a significantly lower normalised biomass compared to the control (two-way ANOVA on BE0 data with soil and P fertiliser as factors, Dunnett's test $P<0.05$ ), while in the Poděbrady soil the normalised aboveground biomass was not significantly different from the control when adding DKP (Dunnett's test, $P>0.05$ ). The addition of straw 

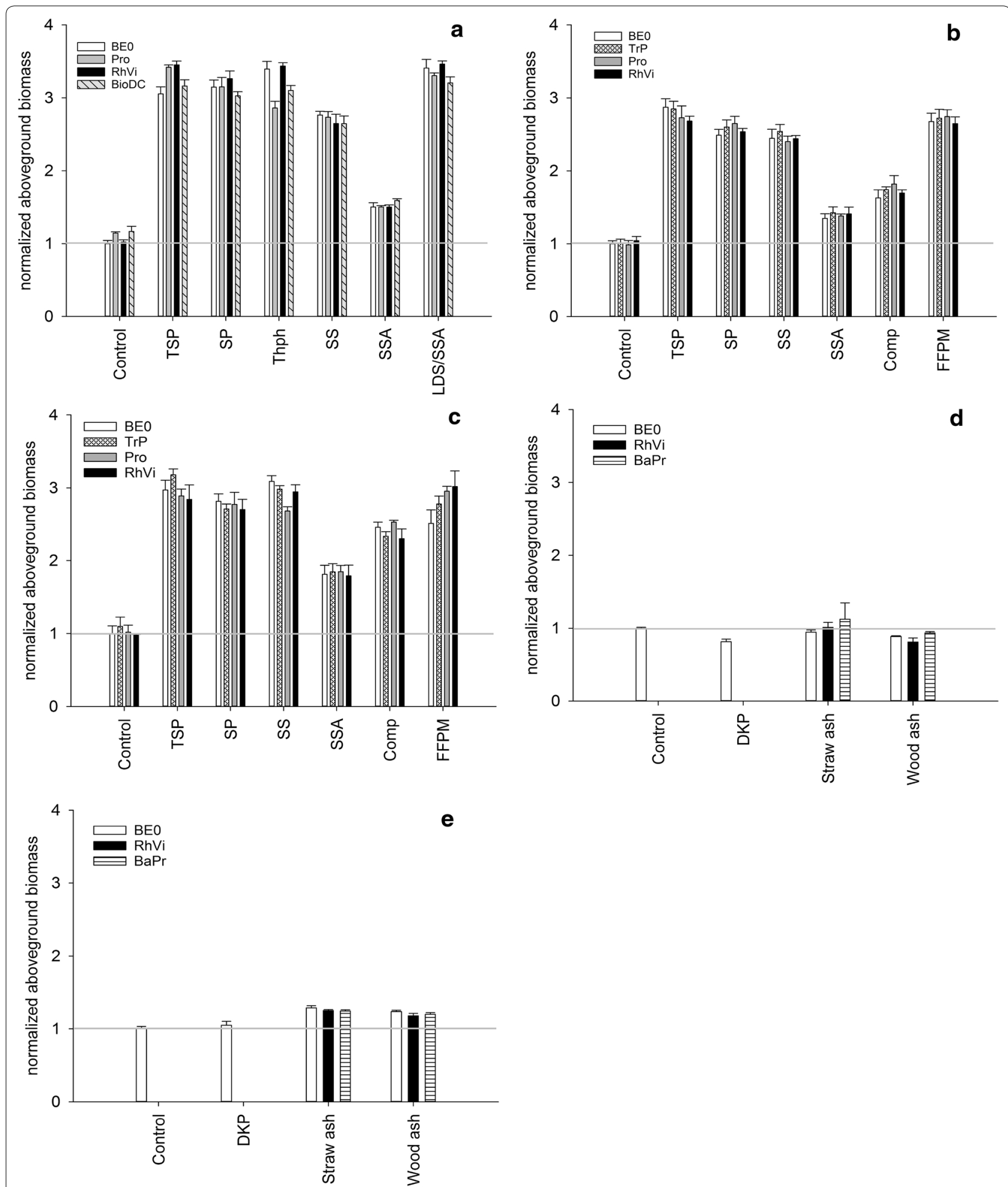

Fig. 1 Normalised aboveground biomass of wheat plants in the HK Kalke (a), UCPH (b, $\mathbf{c})$ and CULS (d, e) experiments. The data are normalised by dividing by the mean of the control treatment (no P fertiliser and BEO) in each experiment and in each of the two soils in $\mathbf{d}$ and $\mathbf{e}$. The following P fertilisers were added in the experiments: no P fertiliser (Control), triple superphosphate (TSP), superphosphate (SP), Thomas phosphate (Thph), sewage sludge (SS), sewage sludge ash (SSA), compost of sewage sludge and garden/park waste (Comp), P-enriched steelmaking slag (LDS/SSA), fibre fraction of pig manure (FFPM), $\mathrm{K}_{2} \mathrm{HPO}_{4}(\mathrm{DKP})$, straw ash and wood ash. The soil was either not inoculated (BE0) or inoculated with Proradix (Pro), RhizoVital (RhVi), biological fertiliser DC (Bio-DC), Trianum P (TrP) or BactoProf (BaPr). Data in $\mathbf{b}$ are for four plants harvested from each pot after 32 days, while data in $\mathbf{c}$ are for five plants harvested after 54 days. The Humpolec soil was used in $\mathbf{d}$ while the Poděbrady soil was used in $\mathbf{e}$ 
Table 6 P content in aboveground biomass ( $\mathrm{mg} \mathrm{P} \mathrm{kg}^{-1}$ soil) in the HK Kalke (a), UCPH (b) and CULS (c) experiments

\begin{tabular}{|c|c|c|c|c|c|}
\hline P fertilizer & Tukey's test (BE0 results) ${ }^{a}$ & Control (BE0) & Pro & RhVi & Bio-DC \\
\hline Control (P0) & a & 3.8 & 5.4 & 4.7 & 4.3 \\
\hline TSP & c & 8.9 & 10.5 & 10.2 & 9.5 \\
\hline Superphosphate & c & 9.4 & 9.6 & 9.4 & 8.6 \\
\hline Sewage sludge & c & 8.7 & 9.8 & 9.8 & 7.8 \\
\hline Sewage sludge ashes & $b$ & 5.3 & 6.1 & 6.1 & 4.2 \\
\hline Thomas phosphate & c & 10.3 & 7.5 & 10.7 & 8.5 \\
\hline LDS/SSA & c & 9.3 & 9.0 & 9.1 & 8.0 \\
\hline \multicolumn{6}{|l|}{ b } \\
\hline & Tukey's test (BE0 results) & Control (BE0) & $\operatorname{TrP}$ & Pro & RhVi \\
\hline Sewage sludge ashes & n.s. & 5.9 & 5.8 & 6.1 & 5.9 \\
\hline FFPM & n.s. & 4.1 & 6.2 & 5.6 & 6.1 \\
\hline \multicolumn{6}{|l|}{ c } \\
\hline P fertilizer & Tukey's test (BEO results) $^{a}$ & Control (BE0) & RhVi & $\mathrm{BaPr}$ & \\
\hline \multicolumn{6}{|l|}{ Humpolec soil } \\
\hline Control (P0) & a & 11.2 & n.a. & n.a. & \\
\hline DKP & a & 10.4 & n.a. & n.a. & \\
\hline Straw ash & $b$ & 13.5 & 14.4 & 16.5 & \\
\hline Wood ash & a & 11.3 & 10.2 & 12.4 & \\
\hline \multicolumn{6}{|l|}{ Poděbrady soil } \\
\hline Control (P0) & A & 12.4 & n.a. & n.a. & \\
\hline DKP & A & 14.4 & n.a. & n.a. & \\
\hline Straw ash & B & 19.8 & 20.2 & 19.1 & \\
\hline Wood ash & $A B$ & 15.6 & 14.2 & 14.9 & \\
\hline
\end{tabular}

a Data were analysed by two-way ANOVA. Data were log-transformed prior to statistical analysis due to unequal variances (Brown-Forsythe test, $P<0.05$ ). Tukey's post hoc test was used to test whether there was a significant difference in $P$ uptake between the different $P$ fertilisers within the BE0 treatment. For each $P$ fertiliser, values in bold italics are significantly higher than the BEO treatment and values in italics are significantly lower than the BEO control according to Dunnett's test

b Data were log-transformed prior to statistical analysis due to unequal variances (Brown-Forsythe test, $P<0.05$ )

c For each of the two soils independently, Tukey's post hoc test was used to test if there was a significant difference in P uptake between the different $P$ fertilisers within the BEO treatment. Small letters indicate differences for the Humpolec soil, while capital letters indicate differences within the Poděbrady soil. For each row, values in bold italics are significantly higher than the BE0 treatment and values in italics are significantly lower than the BE0 control according to Dunnett's test (oneway ANOVA with data for straw ash and wood ash)

a Different letters indicate means that are significantly different

ash resulted in a significantly higher biomass at harvest in the Poděbrady soil (Dunnett's test $P<0.05$ ), while the biomass after adding straw ash was not significantly different from the control without the addition of $\mathrm{P}$ fertiliser in the Humpolec soil (Dunnett's test $P>0.05$ ). Finally, the addition of wood ash led to a significantly lower biomass compared to the control in the Humpolec soil (Dunnett's test $P<0.05$ ), while in contrast the addition of wood ash led to an increase in biomass compared to the control for the Poděbrady soil (Dunnett's test $P<0.05$ ). Overall, there was only a fairly limited difference in the harvested biomass in a comparison across P-fertilisation treatments (Fig. 1d, e). The maximum increase observed when looking across the BE0 treatments was $22 \%$. This increase was observed for both straw and wood ash in the Poderbrady soil. The effect of the addition of the two different ash types (straw and wood ash) in combination with the different $\mathrm{BE}$ inoculation treatments included here (BE0, RhVi, BaPr) was analysed in two separate twoway ANOVAs for the two soils (Humpolec \& Poděbrady) included in this experiment. No significant effect was observed of ash type or BE addition or an interaction between the two factors for any of the two soils investigated ( $P>0.05$, two-way ANOVA). There was a significant effect of soil on $\mathrm{P}$ uptake in the P0/BE0 treatment (Table 6c, one-way ANOVA, $P<0.001$ ). The data for $\mathrm{P}$ content (Table $6 \mathrm{c}$ ) were subsequently analysed for the two soils independently, and a significantly higher P content was observed in the straw ash treatment compared to the control in both soils (Tukey's test, $P<0.05$ ), but the 


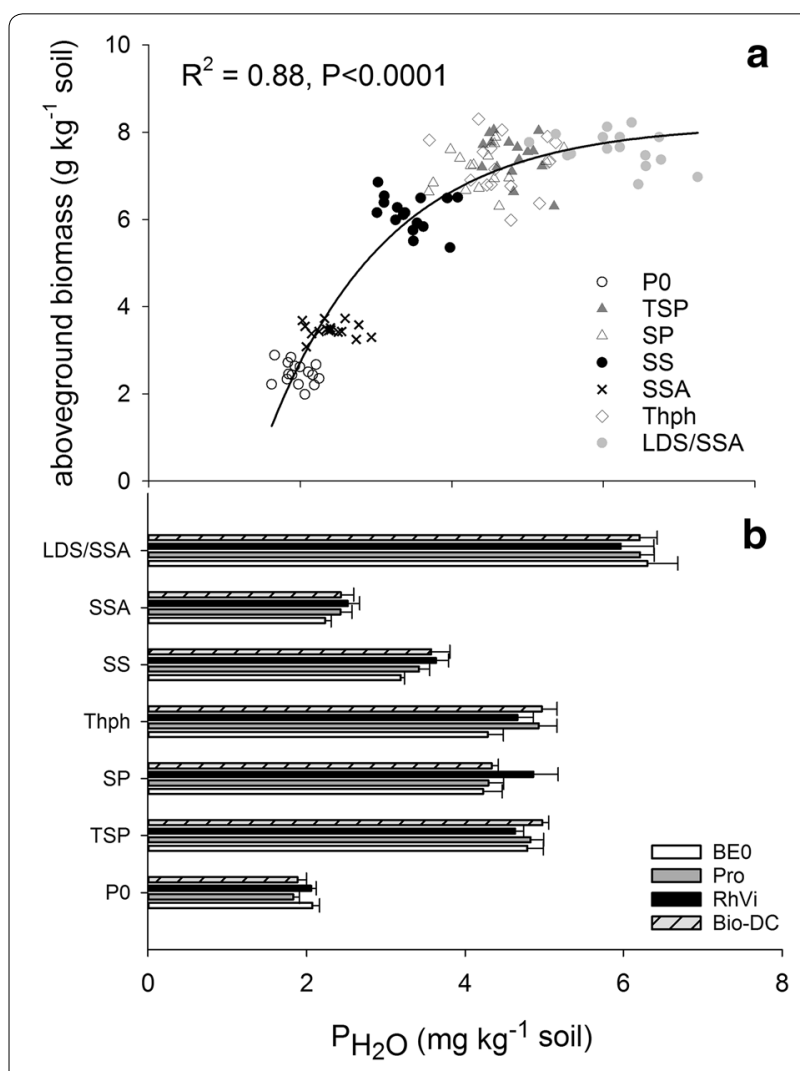

Fig. 2 a Total aboveground biomass of wheat plants in the KALKE experiment as a function of $P_{\mathrm{H}_{2} \mathrm{O}}$ measured after 27 days and $\mathbf{b}$ the measured values of $P_{\mathrm{H}_{2} \mathrm{O}}$ across $P$ fertilisers and $\mathrm{BE}$ treatments. In $\mathbf{a}$, data are fitted to three-parameter functions of the form $y=y_{0}+a \cdot\left[1-e^{(-b \cdot x)}\right] \cdot \ln \mathbf{b}$, each bar represents the mean of data from four replicate samples. Error bars represent SEM. The following P fertilisers were added in the experiment: no P fertiliser (PO), TSP, superphosphate (SP), sewage sludge (SS), sewage sludge ash (SSA), Thomas phosphate (Thph), P-enriched LD slag (LDS/SSA)

BE treatments did not result in a total P content that was significantly different from the control (Dunnett's test, $P>0.05)$.

\section{Soil-available $P$ in the KALKE experiment and relationship with biomass}

Water-extractable $\mathrm{P}\left(\mathrm{P}_{\mathrm{H} 2 \mathrm{O}}\right)$ was able to explain a large part of the variation in the aboveground biomass in the HK Kalke experiment across P-fertilisation treatments and BE treatments (Fig. 2a). Using the Mitscherlich equation, a model with $\mathrm{P}_{\mathrm{H} 2 \mathrm{O}}$ measured after 27 days explained $88 \%$ of the variation in the aboveground biomass (Fig. 2a, $\left.R^{2}=0.88, P<0.0001\right)$. The water-extractable $\mathrm{P}$ in soil was significantly different between the P-fertiliser treatments, and all P-fertiliser treatments were significantly different from the control (Fig. 2b, two-way ANOVA, $P<0.001$ ). The sequence was as follows: $\mathrm{P0}<\mathrm{SSA}<\mathrm{SS}<\mathrm{TSP}=\mathrm{SP}$ $=$ Thph $<$ LDS $/$ SSA. There was no significant effect of BE inoculation on the level of water-extractable $P$ in the pots (two-way ANOVA, $P>0.05$ ) and there was no significant interaction between the two factors (two-way ANOVA, $P>0.05)$.

\section{Correlation between plant $\mathrm{P}$ data and aboveground biomass}

The variation in the aboveground biomass in the UCPH experiment in the BE0 treatments at both harvests (after 32 and 54 days) was explained by the $\mathrm{P}$ concentration in the youngest fully developed leaf harvested from one plant during early growth after 25 days. Using the threeparameter exponential rise to maximum (Mitscherlich) curve equation, highly significant relationships between the two variables were found (Fig. 3: first harvest, $R^{2}=0.73, P<0.0001$; second harvest, $R^{2}=0.78$, $P<0.0001)$.

\section{Fertiliser use efficiencies}

Thomas phosphate and sewage sludge ash-enriched BOF slag both had a relative fertiliser efficiency and relative P-use efficiency comparable to or higher than TSP (Table 7). Sewage sludge tended towards slightly lower relative efficiencies compared to TSP (76-106 \%), but these differences were only significant in the follow-up experiment at UCPH (Table 7). Sewage sludge ash, on the other hand, gave quite low efficiencies (24-31\%) and

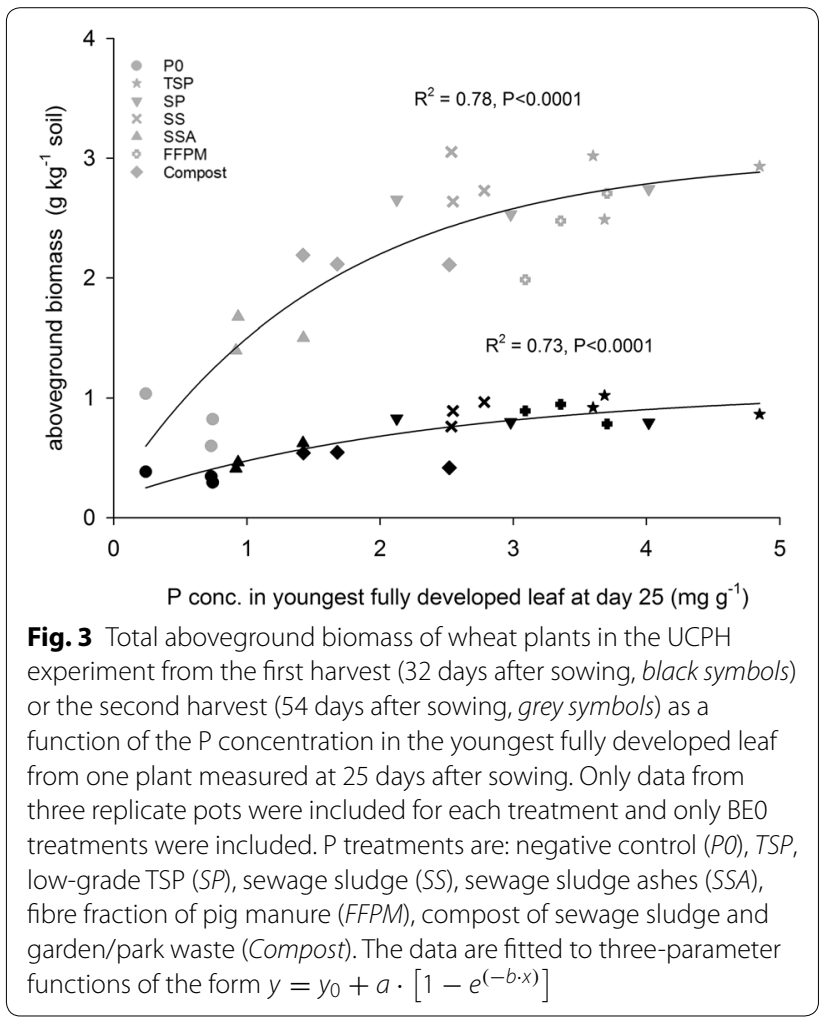


Table 7 Relative fertiliser efficiencies

\begin{tabular}{|c|c|c|c|c|c|}
\hline \multirow[t]{2}{*}{ P fertiliser } & \multicolumn{2}{|c|}{ HK Kalke $(n=4)$} & \multicolumn{2}{|l|}{$\mathrm{UCPH}(n=5)$} & \multirow{2}{*}{$\begin{array}{l}\text { UPCH_2 } 2^{\mathrm{a}}(n=4) \\
\mathrm{FE}(\% \text { of TSP) }\end{array}$} \\
\hline & FE (\% of TSP) & PE (\% of TSP) & $\begin{array}{l}\mathrm{FE}(\% \text { of TSP), } \\
\text { first harvest }\end{array}$ & $\begin{array}{l}\mathrm{FE}(\% \text { of TSP), } \\
\text { second harvest }\end{array}$ & \\
\hline Negative control & $0 \mathrm{a}$ & $0 \mathrm{a}$ & $0 \mathrm{a}$ & $0 \mathrm{a}$ & 0 \\
\hline Triple superphosphate & $100 \mathrm{~cd}$ & $100 \mathrm{~b}$ & $100 \mathrm{c}$ & $100 \mathrm{~cd}$ & $100 \mathrm{c}$ \\
\hline Superphosphate & $104 \mathrm{~cd}$ & $110 \mathrm{~b}$ & $79 c$ & $92 \mathrm{~cd}$ & $103 c$ \\
\hline Thomas phosphate & $117 d$ & $127 b$ & n.a. & n.a. & n.a. \\
\hline Sewage sludge & $86 c$ & $96 b$ & $76 c$ & $106 d$ & $80 \mathrm{~b}$ \\
\hline Sewage sludge ash & $24 b$ & $31 \mathrm{a}$ & $18 \mathrm{ab}$ & $41 \mathrm{~b}$ & $36 a$ \\
\hline Fibre fraction of pig manure & n.a & n.a. & $93 c$ & $77 c$ & n.a. \\
\hline SSA-enriched LD slag & $117 d$ & $108 \mathrm{~b}$ & n.a. & n.a. & n.a. \\
\hline $\begin{array}{l}\text { Compost of sewage sludge and } \\
\text { garden/park waste }\end{array}$ & n.a. & n.a. & $33 b$ & $74 c$ & $54 \mathrm{a}$ \\
\hline
\end{tabular}

The efficiencies are calculated for the BE0 treatment only. Efficiencies are calculated relative to TSP as the positive control (see "Methods"). For each column, different letters after the mean values represent significantly different means (Tukey's test, $P<0.05$ )

a This experiment was partly a replication of the UCPH experiment limited to five plants pot ${ }^{-1}$ (see Additional file 1 for details)

the relative P-use efficiency recorded in the HK Kalke experiment and the relative fertiliser efficiency recorded at the first harvest in the UCPH experiment were not significantly different from the negative control without the addition of a P fertiliser (Table 7). The compost included in the UCPH experiment had a relative fertiliser efficiency (33-74\%) between those of sewage sludge ash and sewage sludge (Table 7).

\section{PCAs on plant compositional data UCPH experiment}

For the UCPH experiment, the elemental composition (B, Ca, Cu, Fe, K, Mg, Mn, P, S, Zn) was analysed in the youngest fully developed leaf sampled after 25 days from the different P-fertilisation treatments (all BE0). The composition was found to be very similar in treatments P1 (TSP), P4 (sewage sludge) and P6 (fibre fraction of pig manure), whereas the treatments P5 (sewage sludge ash) and particularly P0 (no P fertiliser added) were clearly separated in a PCA plot showing the first two principal components (Fig. 4a). The two groups of treatments were partly separated along the first principal component, but were more clearly separated along the second principal component. The loadings of the second principal component (Fig. 4b) showed that the most negative loading seen was for the element $\mathrm{P}$ followed by $\mathrm{Zn}$ and $\mathrm{K}$.

\section{HK Kalke experiment}

The samples were grouped according to the $\mathrm{P}$ fertiliser applied along the first principal component in a PCA on the elemental composition $(\mathrm{Ca}, \mathrm{K}, \mathrm{Mg}, \mathrm{Mn}, \mathrm{Na}, \mathrm{P}$ ) of the aboveground biomass from the final harvest in the HK Kalke experiment (Fig. 5a). There was also a tendency towards a grouping along the second principal component due to the different $\mathrm{BE}$ inoculations across P-fertiliser treatments (Fig. 5b). Thus Proradix treatment was separated from the uninoculated control (BE0) in this plot. When looking at the loadings of the second principal component (Fig. 5c), higher concentrations of $\mathrm{Mn}$ in the BE0 plants were observed to be important for the separation in elemental composition between $\mathrm{BEO}$ and Proradix plants.

\section{CULS experiment}

There was a clear grouping of pots according to the $\mathrm{P}$ fertiliser applied when concentrations of $\mathrm{Ca}, \mathrm{K}, \mathrm{Mg}$, $\mathrm{Mn}, \mathrm{Na}$ and $\mathrm{K}$ in leaves, stems and grain were used in a PCA (Fig. 6a). The clearest separation was between plants that had received no $\mathrm{P}$ fertiliser (P0) and plants that had received straw ash (StA). The treatments were primarily separated along the second principal component, which explained $30.8 \%$ of the variation in the dataset. The loading plot of PC2 (Fig. 6d) shows that higher concentrations of $\mathrm{P}, \mathrm{K}$ and $\mathrm{Mn}$ were especially important for the grouping of samples along the second principal component and that plants that had received straw ash as a fertiliser generally contained higher concentrations of $\mathrm{P}$ and $\mathrm{K}$ in the three tissues investigated compared to the remaining treatments, while higher concentrations of $\mathrm{Mn}$ in plant tissues pulled the samples that had received $\mathrm{P} 0, \mathrm{DKP}$ and $\mathrm{WoA}$ in the opposite direction in the PCA plot (Fig. 6a, d). The samples were grouped along the first principal component according to soil (Humpolec or Poděbrady), where higher concentrations of $\mathrm{P}$ and $\mathrm{Mn}$ were generally observed in plants grown in the Humpolec soil, while higher concentrations of $\mathrm{Ca}$ and $\mathrm{Mg}$ were recorded in plants grown in the Poděbrady soil (Fig. 6a, c). 

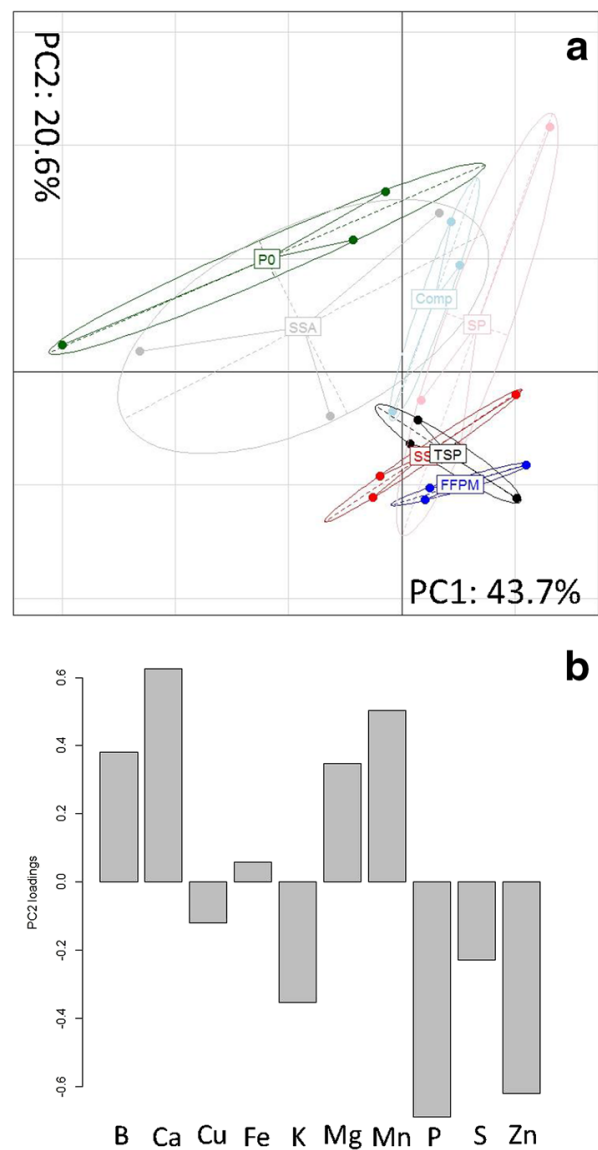

b Fig. 4 Score plot (a) showing the result of a PCA on the elemental
(B, Ca, Cu, Fe, K, Mg, Mn, P, S, Zn) composition of the youngest fully $\mathrm{B}, \mathrm{Ca}, \mathrm{Cu}, \mathrm{Fe}, \mathrm{K}, \mathrm{Mg}, \mathrm{Mn}, \mathrm{P}, \mathrm{S}, \mathrm{Zn}$ )
developed leaf measured at 25 days after sowing in the UCPH experiment. Loading plot (b) showing the loadings of the second principal component. Data are from three replicates of the P-fertilisation treatments PO (control), TSP, SP (superphosphate), SS (sewage sludge), SSA (sewage sludge ash), FFPM (fibre fraction of pig manure) and Comp (compost of sewage sludge and garden/park waste). Pots were not amended with a BE (BEO)

\section{Discussion}

\section{Was $P$ the limiting factor in these experiments?}

These pot experiments were undertaken on the assumption that $\mathrm{P}$ was the limiting factor in these trials. In the case of the UCPH experiment, the clear saturation-type relationship between $\mathrm{P}$ concentration in the youngest fully developed leaf during early growth and the subsequent biomass production (Fig. 3) served as validation that $\mathrm{P}$ limitation was in fact being studied in the $\mathrm{UCPH}$ experiment. Furthermore, the concentration of $P$ recorded in leaves from the unfertilized treatment (Additional file 1: Table S3) was as low as $0.24 \mathrm{mg} \mathrm{g}^{-1}$ in one case and therefore probably within the deficiency
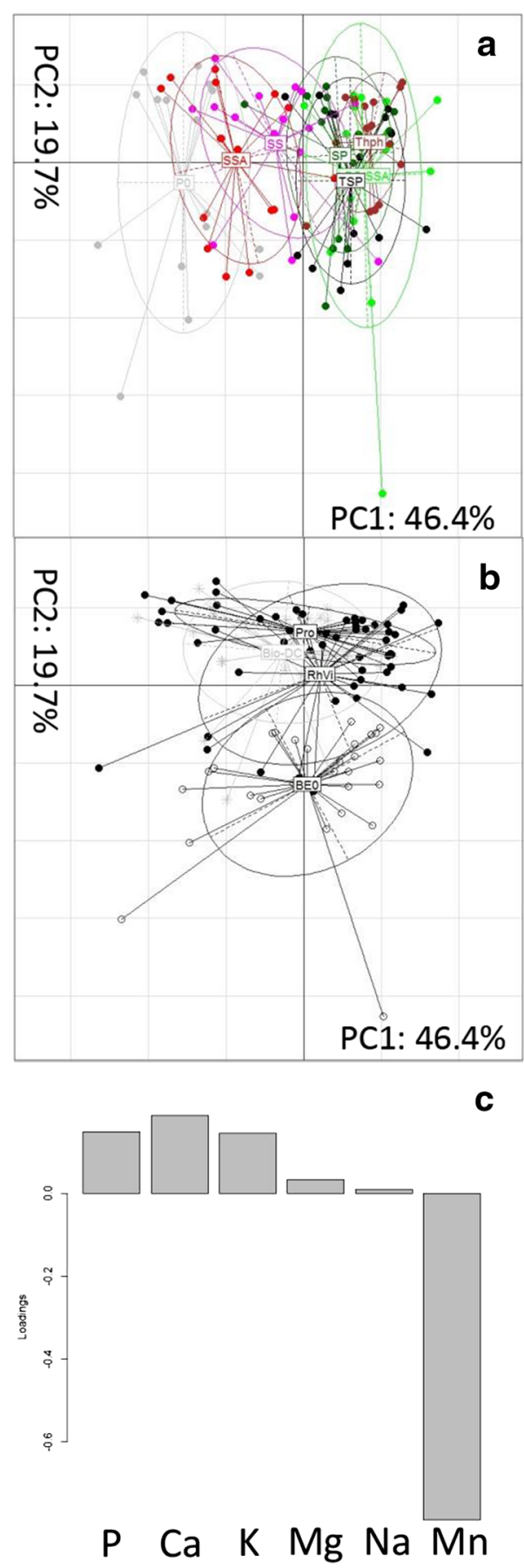

Fig. 5 Score plots $(\mathbf{a}, \mathbf{b})$ showing the result of a PCA on the elemental (Ca, K, Mg, Mn, Na, P) composition of the aboveground biomass grouped either according to $P$ fertiliser applied (a) or BE inoculation (b). Loading plot (c) showing the loadings of the second principal component. Data are from the HK Kalke experiment. Codes for P fertilisers in a negative control (PO), TSP (TSP), superphosphate (SP), Thomas phosphate (Thph), sewage sludge (SS), sewage sludge ash (SSA), SSA-enriched LD slag (LDS/SSA, light green points) 

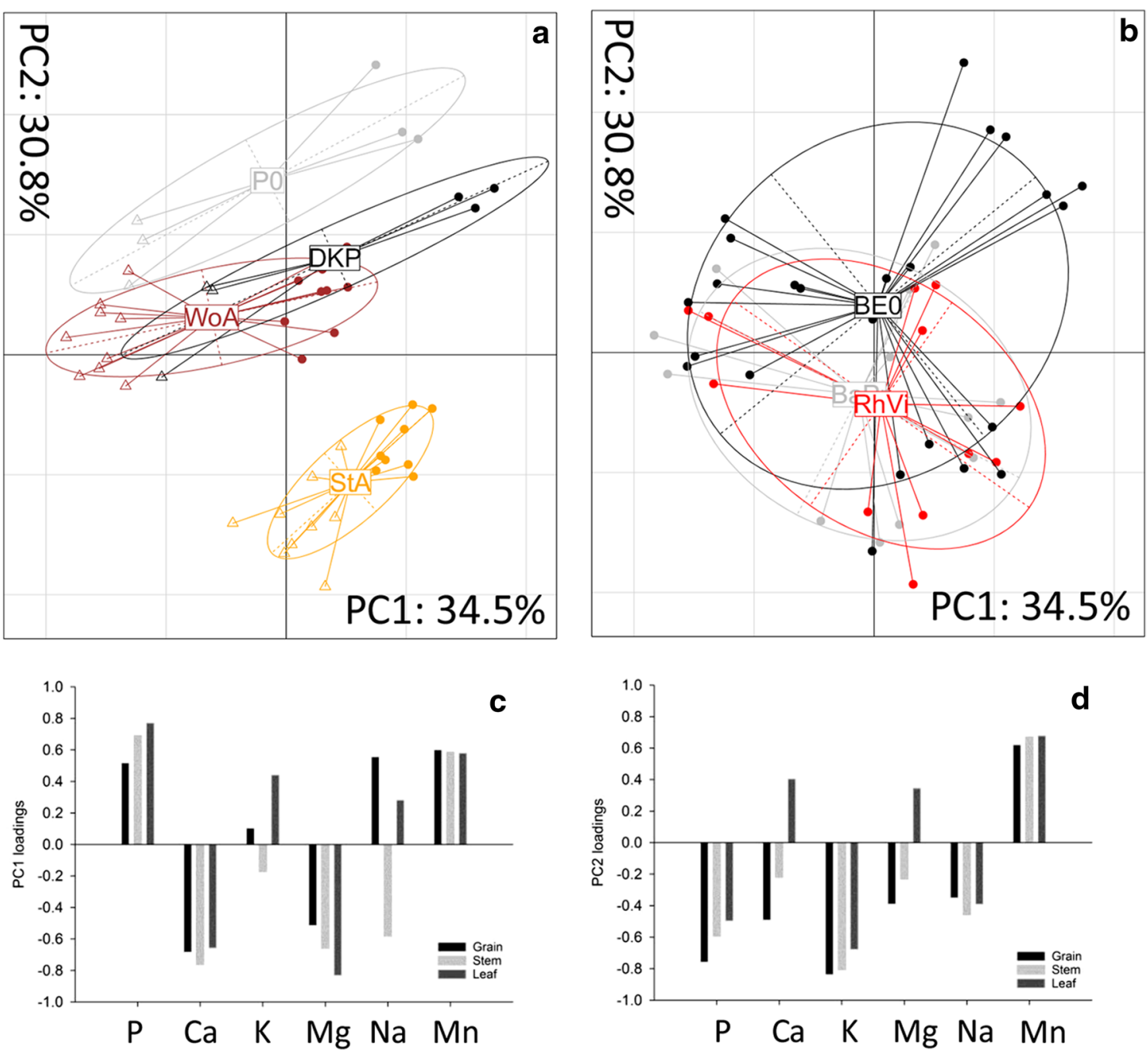

Fig. 6 Score plots ( $\mathbf{a}, \mathbf{b})$ showing the result of a PCA on the elemental (Ca, K, Mg, Mn, Na, P) composition of the grain, stem and leaves. Samples are grouped either according to the P fertiliser applied (a) or BE inoculation (b). In a filled circles represent samples from the Humpolec soil, while open triangles represent samples from the Poděbrady soil. Loading plot (c) showing the loadings of the first principal component. Loading plot (d) showing the loadings of the second principal component. Data are from the CULS experiment

range at this stage [54]. Along the same lines, the clear relationships between soil $\mathrm{P}$ status and aboveground biomass in the HK Kalke experiment (Fig. 2) was validation that $\mathrm{P}$ was the limiting nutrient in the experiment. Here, we did not observe a positive response of $\mathrm{P}$ fertilisation on $\mathrm{P}$ concentration which shows that the $\mathrm{P}$ concentration of the whole shoot after 8 weeks of growth is not a robust measure of $\mathrm{P}$ deficiency. In contrast to the above, $\mathrm{P}$ could not be considered the sole limiting factor in the CULS experiment, since a positive growth response of adding readily soluble DKP $\left(32 \mathrm{mg} \mathrm{kg}^{-1}\right)$ as the $\mathrm{P}$ fertiliser was not observed in this experiment. In general, the concentration of $\mathrm{P}$ was probably in the deficient range across all treatments (below $0.1 \%$ in stem and leaves, Additional file 1: Table S4). This may partly be explained by a nitrogen limitation in the Humpolec soil, since soil solution nitrate levels in the Humpolec soil during the pot experiment were three times lower than those recorded in the Podêbrady soil (data not shown).

\section{Were other nutrients limiting or present in toxic concentrations?}

In the HK Kalke experiment, the concentrations of $\mathrm{Ca}$, $\mathrm{Mg}, \mathrm{Ca}, \mathrm{Mn}$ and $\mathrm{K}$ (Additional file 1: Table S2) were in the adequate range for these elements in wheat shoots at the given growth stage [54].

In the UCPH experiment, the concentrations of $\mathrm{Fe}, \mathrm{K}$, $\mathrm{S}, \mathrm{Zn}$ in the youngest fully developed leaf 25 days after sowing (Additional file 1: Table S3) were within the 
adequate range at this stage [54]. For $\mathrm{B}, \mathrm{Ca}, \mathrm{Cu}, \mathrm{S}$ and $\mathrm{Zn}$ this was also generally the case (Additional file 1: Table S3), but the leaf from one of the three control plants analysed showed concentrations (see minimum in Additional file 1: Table S3) in the deficiency range [54]. For B, the highest concentration recorded $\left(156 \mu \mathrm{g} \mathrm{g}^{-1}\right)$ might be at the limit of toxicity at this stage [54]. However, no clear symptoms were observed.

In the CULS experiment, the grain concentrations of K (Additional file 1: Table S4) indicated deficiency in this element across all treatments, while Mn (Additional file 1: Table S4) was in the adequate range for grain at maturity [54].

\section{Did the added BEs enhance the availability of $P$ from recycled fertiliser products?}

As stated in the introduction, one possible mechanism for improving plant growth by a $\mathrm{BE}$ would be to increase the availability of $\mathrm{P}$ in the soil. When used in combination with recycled fertilisers, it is of interest whether or not the introduced organisms directly affect the solubilisation of the introduced P. In the HK Kalke experiment, no significant effect was observed for any of the tested BEs (Pro, RhVi, Bio-DC) on the level of available P in the soil $\left(\mathrm{P}_{\mathrm{H} 2 \mathrm{O}}\right)$. Since we do not have soil data for the other experiments, we cannot make claims regarding the soil $\mathrm{P}$ availability in these experiments. This is in accordance with previous studies showing that although microbial inoculants may demonstrate potential for solubilisation of sparingly soluble $\mathrm{P}$ sources (such as Ca-phosphates) in vitro, this does not necessarily translate into increased plant availability of $\mathrm{P}$ in the soil [55]. In the present study, there was no support for an increase of plant-available $\mathrm{P}$ in the soil as a result of inoculation with two bacterial products (Proradix and RhizoVital 42) and one fungal product (Biological fertiliser DC). There may be several possible explanations for the lack of a significant positive effect on $\mathrm{P}$ availability: (i) a limited proliferation of the introduced microorganisms in soil due to competition with native microorganisms, for example, (ii) the soil P level may not have been sufficiently low to promote the up-regulation of enzymes involved in P solubilisation, (iii) released $\mathrm{P}$ may have been taken up by the introduced microorganisms without subsequent release to the soil within the time frame of the experiments and finally (iv) the native microbial community of the soil and/or organic waste materials may have been optimal already in making $P$ available from the introduced fertilizers.

\section{Did the added bioeffectors affect the growth of plants and plant $P$ uptake?}

Despite previous reports that the tested organisms may enhance plant growth $[30,43,46]$, only a small positive effect on aboveground biomass of Pro and RhVi in combination with TSP was found (Fig. 1a). The fact that there was only a positive effect in combination with TSP as a fertiliser may point towards a direct effect of the BEs on the plants rather than an effect on $\mathrm{P}$ availability in the soil. This interpretation was also supported by the fact that the uptake of P from TSP-fertilised soil was not significantly different between BE treatments (Table 6a). The direct effects of these microbial inoculants on the plants are in line with earlier work showing that Pro and RhVi may elicit defence responses in plants $[41,56]$, thus directly affecting the plant's metabolism. In the P0 treatment, a positive effect of Pro and RhVi was observed on the total $\mathrm{P}$ content of the aboveground biomass, which seemed to indicate that under these P-limited conditions the two BEs did improve plant $\mathrm{P}$ uptake, even though a BE-mediated increase in $\mathrm{P}_{\mathrm{H} 2 \mathrm{O}}$ was not observed.

As a prerequisite for an effect of BEs on the growth of wheat plants, the successful establishment of organisms in the rhizosphere may be required, and it has been stated that rhizosphere competence may be a key factor in the effectiveness of PGPM $[57,58]$. On the other hand, there is also an example of a study where the supernatant of the culture medium in which T. harzianum T22 was grown resulted in a stronger effect on the growth of maize plants compared to inoculating with spores [30]. This indicates that active growth in the rhizosphere may not always be a prerequisite for an effect of a PGPM and that a direct hormonal effect on the plants is a possible mode of action of these organisms. The present study did not measure whether the microorganisms established themselves in the rhizosphere of the wheat plants, meaning that it cannot be ruled out that the lack of a plant growth-promoting effect of the added BEs was due to an unsuccessful colonisation of the wheat rhizosphere. On the other hand, the fact that a significant $\mathrm{BE}$ effect was seen on the elemental composition of the aboveground biomass in the HK Kalke experiment may be an indication that the added microorganisms were in fact able to establish in the wheat rhizosphere in these pot experiments. In the CULS experiment, the plant elemental composition of the aboveground biomass did not give any indication of a BE effect.

\section{Do the different recycled fertiliser products tested have potential as $\mathrm{P}$ fertilisers?}

A low availability of $P$ in the soil after fertilisation with sewage sludge ash was observed, which translated into a relative fertiliser efficiency based on biomass production of $24-41 \%$ and P uptake of $31 \%$. This result was in line with earlier work, showing that phosphorus in sewage sludge ash is generally not readily taken up by plants [9]. On the other hand, there may be considerable variations 
between different sewage sludge ashes, depending on the processing of sewage sludge in the water treatment plant [7]. Sewage sludge, Thomas phosphate and sewage sludge-enriched BOF slag (LDS/SSA) all resulted in levels of available P similar to or higher than TSP. In fact, fertilisation with LDS/SSA resulted in a significantly higher level of $\mathrm{P}_{\mathrm{H} 2 \mathrm{O}}$ compared to TSP. This was probably related to an increase in soil $\mathrm{pH}$ from $\sim 5.6$ in the TSP treatment to $\sim 6.5$ in the LDS/SSA treatment (Additional file 1: Table S1), since the availability of phosphates in soil is generally highest close to neutrality [59]. Severin et al. [9] found that the LDS/SSA product had high efficiency as a P fertiliser [9] in accordance with this study's results, yielding a P-fertilisation effect comparable to TSP. This shows the potential of this technology to produce a highly effective P fertiliser, partly based on sewage sludge devoid of any organic contaminants. However, the content of heavy metals could potentially be problematic. The content of $\mathrm{Cr}\left(1712 \mathrm{mg} \mathrm{kg}^{-1}\right.$, data not shown) for instance is above the current Danish limits [60], while in Germany contents above $300 \mathrm{mg} \mathrm{kg}^{-1}$ have to be declared [61]. An alternative to using sewage sludge ash could be to use sewage sludge as a fertiliser instead. Concerns may be raised regarding organic contaminants and problematic microorganisms, which are not relevant in the case of sewage sludge ash. However, organic contaminants probably do not pose a great threat here when the quality of present-day sewage sludge is taken into account [4]. In the present study, sewage sludge was observed to possess high potential as a $\mathrm{P}$ fertiliser, resulting in responses that are $76-106 \%$ of those observed when using TSP. This was in relatively good agreement with a pot trial using English ryegrass in which the efficiency of different sludges was $62-86 \%$ of monocalcium phosphate [62]. In the case of wood and straw ash, it was not possible to clearly evaluate their potential as $\mathrm{P}$ fertilisers based on the results presented here. This was due to the fact that (i) the CULS experiment lacked a positive control with the addition of a comparable level of total $\mathrm{P}$ and (ii) the input of $\mathrm{P}$ with the two different ash types was different. These problems aside, from the results presented here, it would not appear that wood ash and straw ash have great potential as $P$ fertilisers, since the relative increase in biomass yield was not above $25 \%$ in comparison to the HK Kalke and UCPH experiments showing yield increases of $50 \%$ or more, even for sewage sludge ash. This result contradicted an earlier study in which a high P-fertilisation effect was found for rape meal, straw and cereal ashes [63]. However, as observed from the PCA plot, a small effect was observed on the plant elemental composition due to the wood ash and DKP treatments and greater effect of the straw ash treatment, but these differences were not clearly associated with differences in the aboveground biomass. These effects were observed to be independent of soil type. The fibre fraction of pig manure (FFPM) prepared using a decanter centrifuge was shown to have a high fertiliser efficiency that was not significantly lower than the positive TSP control. This was in accordance with previous results showing a high $\mathrm{P}$ availability after application of this solid manure fraction to soil [64].

\section{Conclusions}

Based on the results from the HK Kalke experiment, we did not find evidence to support the hypothesis that $\mathrm{BE}$ products increase the availability of $\mathrm{P}$ in the soil. Furthermore, the BE products only had a very limited effect on the growth of wheat plants across all experiments. Further work is therefore needed to elucidate whether inoculation with BEs has agronomic potential in wheat production. A number of the tested recycled P-fertiliser products (sewage sludge, P-enriched BOF slag and fibre fraction of pig manure) were shown in the HK Kalke and UCPH experiments to have a high potential as $\mathrm{P}$ fertilisers without a requirement for further processing.

\section{Additional file}

Additional file 1. Fig. S1. Biomass in the UCPH follow-up experiment. Table S1. Data on soil pH from the HK Kalke experiment and Tables S2S4. Data on plant elemental composition from the HK Kalke (Table S2), UCPH (Table S3) and CULS (Table S4) experiments.

\section{Authors' contributions \\ JDSL carried out the UCPH experiments, performed the majority of the data analysis in the paper and wrote the paper. MR carried out the HK Kalke experiment, contributed to data analysis and discussions of data. FM carried out the CULS experiment and performed the plant analyses for this experi- ment. MK supervised the analyses in the CULS experiment. PT supervised the experimental design in the CULS experiment. JM contributed to discussions regarding data interpretation. AN contributed to experimental design, data interpretation and the writing of the paper. All authors contributed to initial discussions of data. All authors read and approved the final manuscript.}

\section{Author details \\ ${ }^{1}$ Department of Plant and Environmental Sciences, Section of Plant and Soil Science, University of Copenhagen, Thorvaldsensvej 40, 1871 Frederiksberg, Denmark. ${ }^{2}$ Institut für Baustoff Forschung, Bliersheimer Straße 62, Rhein- hausen, 47229 Duisburg, Germany. ${ }^{3}$ Department of Agroenvironmental Chemistry and Plant Nutrition, Faculty of Agrobiology, Food and Natural Resources, Czech University of Life Sciences Prague, Kamycka 129, 6 Suchdol, 16521 Prague, Czech Republic.}

\section{Acknowledgements}

This study was funded by the European Community's Seventh Framework Programme 662 (FP7/2007-2013) under Grant Agreement no. 312117 (BIOFECTOR).

\section{Competing interests}

The authors declare that they have no competing interests.

Received: 25 January 2016 Accepted: 29 May 2016

Published online: 05 September 2016 


\section{References}

1. Dawson CJ, Hilton J. Fertiliser availability in a resource-limited world: production and recycling of nitrogen and phosphorus. Food Policy. 2011;36:S14-22.

2. Hilton J. Johnston AE, Dawson CJ. The phosphate life-cycle: rethinking the options for a finite resource. In: Proceedings-International Fertiliser Society. 2010. International Fertiliser Society.

3. Karunanithi $R$, et al. Phosphorus recovery and reuse from waste streams. Adv Agron. 2015;131:173-250.

4. Smith SR. Organic contaminants in sewage sludge (biosolids) and their significance for agricultural recycling. Philos Trans A Math Phys Eng Sci. 2009;367(1904):4005-41.

5. Donatello S, Cheeseman CR. Recycling and recovery routes for incinerated sewage sludge ash (ISSA): a review. Waste Manag. 2013;33(11):2328-40.

6. Lamprecht $\mathrm{H}$, et al. The trade-off between phosphorus recycling and health protection during the BSE crisis in Switzerland. A. Gaia Ecol Perspect Sci Soc. 2011;20(2):112-21.

7. Nanzer $\mathrm{S}$, et al. The molecular environment of phosphorus in sewage sludge ash: implications for bioavailability. J Environ Qual. 2014;43(3):1050-60

8. Branca TA, et al. Investigation of (BOF) converter slag use for agriculture in europe. Metall Res Technol. 2014;111(3):155-67.

9. Severin $M$, et al. Phosphate fertilizer value of heat treated sewage sludge ash. Plant Soil Environ. 2014;60(12):555-61.

10. Popovic O, Hjorth M, Jensen LS. Phosphorus, copper and zinc in solid and liquid fractions from full-scale and laboratory-separated pig slurry. Environ Technol. 2012;33(18):2119-31.

11. Leytem AB, Turner BL, Thacker PA. Phosphorus composition of manure from swine fed low-phytate grains: evidence for hydrolysis in the animal. J Environ Qual. 2004;33(6):2380-3.

12. Schlemmer $U$, et al. Degradation of phytate in the gut of pigs-pathway of gastrointestinal inositol phosphate hydrolysis and enzymes involved. Arch Tierernahr. 2001;55(4):255-80.

13. Brod $\mathrm{E}$, et al. Waste products as alternative phosphorus fertilisers part I: inorganic $\mathrm{P}$ species affect fertilisation effects depending on soil $\mathrm{pH}$. Nutr Cycl Agroecosyst. 2015;103(2):167-85.

14. Halpern M, et al. Chapter two-the use of biostimulants for enhancing nutrient uptake. Adv Agron. 2015;130:141-74.

15. du Jardin P. Plant biostimulants: definition, concept, main categories and regulation. Sci Hortic. 2015;196:3-14.

16. Vessey JK. Plant growth promoting rhizobacteria as biofertilizers. Plant Soil. 2003;255(2):571-86.

17. Rudresh DL, Shivaprakash MK, Prasad RD. Tricalcium phosphate solubilizing abilities of Trichoderma spp. in relation to $P$ uptake and growth and yield parameters of chickpea (Cicer arietinum L.). Can J Microbiol. 2005;51(3):217-22.

18. Khan AA, et al. Phosphorus solubilizing bacteria: occurrence, mechanisms and their role in crop production. J Agric Biol Sci. 2009;1(1):48-58.

19. Khan MS, et al. Plant growth promotion by phosphate solubilizing fungi-current perspective. Arch Agron Soil Sci. 2010;56(1):73-98

20. Kucey R. Increased phosphorus uptake by wheat and field beans inoculated with a phosphorus-solubilizing Penicillium bilaji strain and with vesicular-arbuscular mycorrhizal fungi. Appl Environ Microbiol. 1987;53(12):2699-703

21. Leggett $M$, et al. Maize yield response to a phosphorus-solubilizing microbial inoculant in field trials. J Agric Sci. 2014;153:1464-78.

22. Singh S, Kapoor KK. Inoculation with phosphate-solubilizing microorganisms and a vesicular arbuscular mycorrhizal fungus improves dry matter yield and nutrient uptake by wheat grown in a sandy soil. Biol Fertil Soils. 1999;28(2):139-44.

23. Richardson $A E$, et al. Plant mechanisms to optimise access to soil phosphorus. Crop Pasture Sci. 2009:60(2):124-43.

24. Richardson AE. Prospects for using soil microorganisms to improve the acquisition of phosphorus by plants. Funct Plant Boil. 2001;28(9):897-906.

25. Harman GE, et al. Trichoderma species-opportunistic, avirulent plant symbionts. Nat Rev Microbiol. 2004:2(1):43-56.

26. Shoresh M, Harman GE, Mastouri F. Induced systemic resistance and plant responses to fungal biocontrol agents. Annu Rev Phytopathol. 2010;48:21-43.

27. Harman GE. Overview of mechanisms and uses of trichoderma spp. Phytopathology. 2006;96(2):190-4
28. Altomare $\mathrm{C}$, et al. Solubilization of phosphates and micronutrients by the plant-growth-promoting and biocontrol fungus Trichoderma harzianum Rifai 1295-22. Appl Environ Microbiol. 1999;65(7):2926-33.

29. Adams P, De-Leij F, Lynch J. Trichoderma harzianum Rifai 1295-22 mediates growth promotion of crack willow (Salix fragilis) saplings in both clean and metal-contaminated soil. Microb Ecol. 2007;54(2):306-13.

30. Akladious SA, Abbas SM. Application of Trichoderma harzianum T22 as a biofertilizer potential in maize growth. J Plant Nutr. 2014;37(1):30-49.

31. Takeda M, Knight JD. Enhanced solubilization of rock phosphate by Penicillium bilaiae in pH-buffered solution culture. Can J Microbiol. 2006;52(11):1121-9.

32. Wakelin SA, et al. Phosphate solubilization by Penicillium spp. closely associated with wheat roots. Biol Fertil Soils. 2004;40(1):36-43.

33. Wakelin SA, et al. The effect of Penicillium fungi on plant growth and phosphorus mobilization in neutral to alkaline soils from southern Australia. Can J Microbiol. 2007:53(1):106-15.

34. Vessey JK, Heisinger KG. Effect of Penicillium bilaii inoculation and phosphorus fertilisation on root and shoot parameters of field-grown pea. Can J Plant Sci. 2001;81(3):361-6.

35. Karamanos R, Flore N, Harapiak J. Re-visiting use of Penicillium bilaii with phosphorus fertilization of hard red spring wheat. Can J Plant Sci. 2010;90(3):265-77.

36. Grayston SJ, et al. Selective influence of plant species on microbial diversity in the rhizosphere. Soil Biol Biochem. 1998;30(3):369-78.

37. Buddrus-Schiemann K, et al. Root colonization by Pseudomonas sp. DSMZ 13134 and impact on the indigenous rhizosphere bacterial community of barley. Microb Ecol. 2010;60(2):381-93.

38. Mäder $\mathrm{P}$, et al. Inoculation of root microorganisms for sustainable wheat-rice and wheat-black gram rotations in India. Soil Biol Biochem. 2011;43(3):609-19.

39. Haque M, Khan M. Effects of phosphatic biofertilizer with inorganic and organic sources of phosphorus on growth and yield of lentil. J Environ Sci Nat Resour. 2013:5(2):225-30.

40. Moszcyńska E, Pytlarz-Kozicka M, Grzeszczuk J. The impact of applying biological treatment on the infection of potato tubers by the fungus rhizoctonia solani and the bacterium streptomyces scabiei. J Res Appl Agric Eng. 2015;60(4):46.

41. Von Rad U, Mueller MJ, Durner J. Evaluation of natural and synthetic stimulants of plant immunity by microarray technology. New Phytol. 2005:165(1):191-202

42. Arndt W. Pseudomonas used for the treatment of plants and/or seeds and incubated in a culture containing phosphorus compounds, nitrogen compounds and succinic acid. 2005. Google Patents.

43. Fröhlich $\mathrm{A}$, et al. Response of barley to root colonization by Pseudomonas sp. DSMZ 13134 under laboratory, greenhouse, and field conditions. J Plant Interact. 2012;7(1):1-9.

44. Krebs B, et al. Use of Bacillus subtilis as biocontrol agent. I. Activities and characterization of Bacillus subtilis strains. Zeitschrift für Pflanzenkrankheiten und Pflanzenschutz. 1998;105(2):181-97.

45. Borriss R, et al. Relationship of Bacillus amyloliquefaciens clades associated with strains DSM 7(T) and FZB42(T): a proposal for Bacillus amyloliquefaciens subsp amyloliquefaciens subsp nov and Bacillus amyloliquefaciens subsp plantarum subsp nov based on complete genome sequence comparisons. Int J Syst Evol Microbiol. 2011;61:1786-801.

46. Borriss R. Use of plant-associated Bacillus strains as biofertilizers and biocontrol agents in agriculture, in bacteria in agrobiology: plant growth responses. Berlin: Springer; 2011. p. 41-76.

47. Bákonyi $\mathrm{N}$, et al. Comparison of effects of different biofertilisers on early development of cucumber and wheat seedlings. In Zbornik Radova 44. Hrvatski i 4 Medunarodni Simpozij Agronoma, Opatija, Hrvatska, 16-20 Veljače 2009. 2009. Poljoprivredni Fakultet Sveučilišta Josipa Jurja Strossmayera u Osijeku.

48. VDLUFA M. Band 1. Die Untersuchung von Böden. Darmstadt:VDLUFAVerlag; 1991.

49. Van der Paauw F, Sissingh HA, Ris J. An improved method of water extraction for the assessment of soil phosphate supply: Pw value. Verslag. Landbollwk. Onderzoek. 1971. 749. (Dutch with an English summary).

50. Murphy J, Riley JP. A modified single solution method for the determination of phosphate in natural waters. Anal Chim Acta. 1962;27:31-6.

51. Mason S, et al. Prediction of wheat response to an application of phosphorus under field conditions using diffusive gradients in thin-films (DGT) and extraction methods. Plant Soil. 2010;337(1-2):243-58. 
52. Team RC. A language and environment for statistical computing. Vienna: R Foundation for Statistical Computing; 2014

53. Chessel D, Dufour AB, Thioulouse J. The ade4 package-I-One-table methods. R News. 2004;4(1):5-10.

54. Reuter DJ. Plant analysis: an interpretation manual. Clayton: CSIRO Publishing; 1997.

55. Khan MS, Zaidi A, Wani PA. Role of phosphate-solubilizing microorganisms in sustainable agriculture-a review. Agron Sustain Dev. 2007;27(1):29-43

56. Qiao JQ, et al. Stimulation of plant growth and biocontrol by Bacillus amyloliquefaciens subsp. plantarum FZB42 engineered for improved action. Chem Biol Technol Agric. 2014;1(1):1-14.

57. Lugtenberg BJ, Dekkers LC. What makes Pseudomonas bacteria rhizosphere competent? Environ Microbiol. 1999;1 (1):9-13.

58. Kucey $R$, Janzen $H$, Leggett M. Microbially mediated increases in plantavailable phosphorus. Adv Agron. 1989;42(199228):60525-8.

59. Brady NC, Weil RR. The nature and properties of soils. Upper Saddle River: Prentice-Hall Inc.; 1996.
60. MST. Executive order on the use of waste for agricultural purposes (Bekendtgørelse om anvendelse af affald til jordbrugsformål, Slambekendtgørelsen). Danish environmental protection agency (Miljøstyrelsen): Copenhagen, Denmark. 2006. (In Danish).

61. German Federal Ministry for food, a.a.c.p., Regulation on the placing of fertilisers, soil additives, growing media and plant additives (Verordnung über das Inverkehrbringen von Düngemitteln, Bodenhilfsstoffen, Kultursubstraten und Pflanzenhilfsmittel. Bundesgesetzblatt Teil I, 2012; 58. (In German).

62. Frossard E, et al. The fate of sludge phosphorus in soil-plant systems. Soil Sci Soc Am J. 1996:60(4):1248-53.

63. Schiemenz K, et al. Phosphorus fertilizing effects of biomass ashes, in recycling of biomass ashes. Berlin: Springer; 2011. p. 17-31.

64. Christel W, et al. Pig slurry acidification, separation technology and thermal conversion affect phosphorus availability in soil amended with the derived solid fractions, chars or ashes. Plant Soil. 2016;401(1):93-107.

\section{Submit your manuscript to a SpringerOpen ${ }^{\circ}$ journal and benefit from:}

- Convenient online submission

- Rigorous peer review

- Immediate publication on acceptance

- Open access: articles freely available online

- High visibility within the field

- Retaining the copyright to your article 